\title{
Biocontrol Activity and Induction of Systemic Resistance in Pepper by Compost Water Extracts Against Phytophthora capsici
}

\author{
Mee Kyung Sang, Jeong-Gyu Kim, and Ki Deok Kim
}

First and third authors: Laboratory of Plant Disease and Biocontrol, and second author: Division of Environmental Science and Ecological Engineering, College of Life Sciences and Biotechnology, Korea University, Seoul 136-713, Republic of Korea. Accepted for publication 12 April 2010.

\begin{abstract}
Sang, M. K., Kim, J.-G., and Kim, K. D. 2010. Biocontrol activity and induction of systemic resistance in pepper by compost water extracts against Phytophthora capsici. Phytopathology 100:774-783.

We investigated the effects of water extracts of composts (CWE) from commercial compost facilities for controlling root and foliar infection of pepper plants by Phytophthora capsici. Among $47 \mathrm{CWE}$ tested, CWE from composts Iljuk-3, Iljuk-7, Shinong-8, and Shinong-9 significantly $(P<0.05)$ inhibited zoospore germination, germ tube elongation, mycelial growth, and population of $P$. capsici. All selected CWE significantly $(P<0.05)$ reduced the disease incidence and severity in the seedling and plant assays compared with the controls. However, there were no significant differences in zoospore germination, disease incidence, and disease severity between treatments of untreated, autoclaved, and filtered CWE. In addition, CWE significantly $(P<0.05)$ suppressed

CAChi2, CaPR-4, CAPO1, or CaPR-10 as well as $\beta-1,3$-glucanase, chitinase, and peroxidase activities, which resulted in enhanced plant defense against $P$. capsici in pepper plants. Moreover, the CWE enhanced the chemical and structural defenses of the plants, including $\mathrm{H}_{2} \mathrm{O}_{2}$ generation in the leaves and lignin accumulation in the stems. The CWE could also suppress other fungal pathogens (Colletotrichum coccodes in pepper leaves and $C$. orbiculare in cucumber leaves) through ISR; however, it failed to inhibit other bacterial pathogens (Xanthomonas campestris pv. vesicatoria in pepper leaves and Pseudomonas syringae pv. lachrymans in cucumber leaves). These results suggest that a heatstable chemical(s) in the CWE can suppress root and foliar infection by $P$. capsici in pepper plants. In addition, these suppressions might result from direct inhibition of development and population of $P$. capsici for root infection, as well as indirect inhibition of foliar infection through ISR with broad-spectrum protection.
\end{abstract} leaf infection of $P$. capsici through induced systemic resistance (ISR) in plants root-drenched with CWE. The tested CWE enhanced the expression of the pathogenesis-related genes, CABPR1, CABGLU,
Additional keywords: hydrogen peroxide.
Composts as fertilizers to increase soil nutrients have been used to recycle enormous amounts of organic wastes such as green manures, farmyard manures, household wastes, livestock manures, and sewage sludges (15). In Korea, livestock manures are commonly used as the main raw material for commercial composts, and $\approx 70 \%$ of livestock wastes were recycled in recent years (40). During the composting process, a number of chemical and physical properties such as temperature, aeration, moisture, $\mathrm{C}: \mathrm{N}$ ratio, $\mathrm{pH}$, and cation exchange capacity were changed, which results in the composts being useful for agriculture as fertilizers $(6,22)$.

Various composts and their water extracts can be used to control plant diseases caused by many soilborne and airborne pathogens such as Colletotrichum orbiculare, Fusarium spp., Pythium spp., Phytophthora spp., Rhizoctonia solani, Sclerotium rolfsii, Venturia inaequalis, and Xanthomonas vesicatoria $(2,10,13,14,16,18,27,29,49,50,56,57)$. In addition, biotic and abiotic factors in these composts have been found to be associated with the suppression of various plant diseases $(9,18)$. The physical and chemical factors of composts often alter soil properties and microflora structures, which can reduce the populations of plant pathogens $(3,29)$. Diab et al. (14) reported that potting mix amended with composted swine waste showed enhanced microbial activity and suppressed levels of $R$. solani. These increased microbial activities may contribute to the suppressive activity of

Corresponding author: K. D. Kim; E-mail address: kidkim@korea.ac.kr

doi:10.1094/PHYTO-100-8-0774

(c) 2010 The American Phytopathological Society compost-amended soil by competition, antibiosis, parasitism, or predation. The compost itself and altered microbial activity could also induce systemic resistance in plants, which would lead to reduce disease developments (53). Previously, Zhang et al. (56) reported that a biocontrol agent fortified-composted pine bark mix could elicit induced systemic resistance (ISR) against $C$. orbiculare in cucumber. On the other hand, Conn et al. (12) reported that volatile fatty acid, nitrous acid, and ammonia in liquid swine manure inactivated the microsclerotia of Verticillium dahliae in soil. Moreover, Zmora-Nahum et al. (57) found that basic $\mathrm{pH}$ and high $\mathrm{NH}_{3}$ concentration in municipal sewage sludge and yard waste compost were related to inhibition of sclerotia germination of $S$. rolfsii.

Recently, Walters (55) suggested that plants interact continuously with biotic (mycorrhiza, endophytes, insects, nematodes, plant growth-promoting rhizobacteria, and other root-associated microbes) and abiotic (osmotic stress, proton stress, and mineral nutrition) environments in the field, which might likely lead to the induction of resistance against plant pathogens and environmental stresses. The ISR triggers suggested by Walters (55) may exist in traditional agricultural practices with composts in the field. Practically, these triggers could be flowed out as water-soluble components from composts into the soil by rain or irrigation water. As a result, cultivated plants may be protected through direct or indirect suppression against infection of plant pathogens without additional application of disease-control measures.

Phytophthora blight of pepper (Capsicum annuum L.) caused by the oomycete pathogen Phytophthora capsici is one of the most significant limits in its production worldwide $(21,23)$. The disease is difficult to control because $P$. capsici, as a soilborne 
pathogen, can infect not only roots and crowns but also other parts of pepper plants via water splashing from the soil to the foliage (46). Chemicals such as metalaxyl and captafol have been used widely to control this disease; however, these chemicals are expensive for application in the field, have potential to damage the environment, and lead to the development of resistant isolates $(21,43)$. Alternatively, biological controls with antagonistic microorganisms, composts, and organic amendments have been introduced for sustainable disease management with reduction of potential hazards to the environment $(2,26,27,29,32,47,48)$. Recently, Joshi et al. (24) reported that composts had suppressive effects on soilborne and foliar diseases of French bean plants in the field. Similarly, composts have been used to control root infection by $P$. capsici in pepper plants $(27,28,29)$; however, the use of composts or their water extracts has been little studied to control foliar infection by the pathogen through ISR. Therefore, in this study, we (i) investigated the direct and indirect effects of water extracts of composts (CWE) from commercial compost facilities for controlling root and foliar infection by $P$. capsici on pepper and (ii) evaluated the indirect effects of CWE against other fungal pathogens such as Colletotrichum coccodes on pepper and C. orbiculare on cucumber, as well as other bacterial pathogens such as X. campestris pv. vesicatoria on pepper and Pseudomonas syringae pv. lachrymans on cucumber. In addition, we evaluated disease suppression by CWE to determine whether it resulted from biotic or abiotic factors.

\section{MATERIALS AND METHODS}

Compost and CWE preparation. In total, 47 compost samples from six commercial compost facilities, including Changsung (Pocheon, Korea), Guman (Geuman, Korea), Iljuk (Iljuk, Korea), Shinong (Pocheon, Korea), Taenong (Icheon, Korea), and Taewon (Sangju, Korea), were used in this study, and their components and physicochemical properties are described in Table 1. To prepare the CWE, $20 \mathrm{~g}$ of compost were incubated with $100 \mathrm{ml}$ of sterile distilled water in a rotary shaking incubator $(160 \mathrm{rpm})$ at $28^{\circ} \mathrm{C}$ for $30 \mathrm{~min}$ and filtered through four layers of sterile cheesecloth. However, for a microscopic observation of $P$. capsici, these filtrates were further filtered through a Whatman no. 1 filter paper. In this study, 20\% CWE (compost/distilled water, wt/vol) was used as the initially prepared concentration because it was the highest concentration obtained from extracting the composts with water.

Pepper plant and inoculum. For seedling and plant assays, 2and 5-week-old pepper (cv. Nockwang) plants, respectively, were prepared. Pepper seed were sown in 128-cell ( 3 by 3 by $5 \mathrm{~cm}$ ) plug trays filled with potting mixture $(6 \mathrm{~g}$ dry weight/cell) (peat moss [Acadian Peat Moss Ltd., Lamègue, New Brunswick, Canada] and TKS2 [Floragard Product, Oldenburg, Germany], $1: 1.5, \mathrm{vol} / \mathrm{vol}$ ) and then placed at room temperature in a growth room with fluorescent light at $16 \mathrm{~h} /$ day. Three weeks after sowing, the seedlings were transplanted to 10 -cm-diameter pots containing the same potting mixtures and further grown under the same conditions for plant assays.

The pathogen inoculum was prepared as described by Kim et al. (27). Briefly, P. capsici S197 was precultured on V8 juice agar for 4 days at $28^{\circ} \mathrm{C}$. The mycelial plugs $(5 \mathrm{~mm}$ in diameter) were inoculated and grown on oatmeal agar for 7 days at $28^{\circ} \mathrm{C}$. These cultures were then applied with $20 \mathrm{ml}$ of sterile distilled water and incubated under continuous fluorescent light for an additional 7 days at $28^{\circ} \mathrm{C}$ to induce the formation of zoosporangia. Next, the cultures were added with $5 \mathrm{ml}$ of chilled sterile water and stored at $4{ }^{\circ} \mathrm{C}$ for $30 \mathrm{~min}$, followed by incubation at room temperature for $30 \mathrm{~min}$ to release the zoospores from zoosporangia. Mycelia and sporangial debris were removed from the zoospores by filtration through three layers of sterile cheesecloth. The zoospore concentration was determined using a hemacytometer after vortexing $1 \mathrm{ml}$ of the zoospore suspension for $30 \mathrm{~s}$ to induce the zoospores to encyst.

Inhibition of $\boldsymbol{P}$. capsici germination and growth. Based on our preliminary experiment, a $1: 1$ ( $\mathrm{vol} / \mathrm{vol})$ mixture of $20 \%$ (wt/vol) CWE and zoospore suspension was prepared to examine the effects of CWE on zoospores. A drop (10\% [wt/vol] CWE, actual concentration) of the mixture $(1: 1, \mathrm{vol} / \mathrm{vol})$ of $20 \%$ (wt/vol) CWE or sterile distilled water (control), and the suspension of encysted zoospores of $P$. capsici prepared as mentioned above on a glass slide was incubated at $28^{\circ} \mathrm{C}$. Two hours after incubation, zoospore germination was examined microscopically by evaluation of $\approx 100$ zoospores per observation (three times per replicate). Based on these initial evaluations with the $47 \mathrm{CWE}$, four CWE from Iljuk-3, Iljuk-7, Shinong-8, and Shinong-9 were selected for further tests due to their consistent and significant inhibitions of zoospore germination compared with the water controls.

Next, inhibition of the germination rate, germ tube elongation, and mycelial growth of $P$. capsici by the selected CWE was evaluated. Specifically, germination rate $(\%)$ and germ tube length $(\mu \mathrm{m})$ were determined as mentioned above. To evaluate the mycelial growth, five mycelial plugs $(5 \mathrm{~mm}$ in diameter) from the edges of the cultures grown on V8 juice agar for 4 days were inoculated in $20 \mathrm{ml}$ of a 1:1 (vol/vol) mixture of V8 juice broth and $20 \%$ (wt/vol) CWE or sterile distilled water (control) and incubated in a rotary shaking incubator $(160 \mathrm{rpm})$ at $28^{\circ} \mathrm{C}$ for 10 days. The cultures were then passed through a filter paper

TABLE 1. Sample numbers, compositions, composting conditions, and physicochemical properties of organic byproducts used in this study

\begin{tabular}{|c|c|c|c|c|c|c|c|c|c|c|c|c|c|c|}
\hline \multirow[b]{2}{*}{$\begin{array}{l}\text { Compost } \\
\text { facility }\end{array}$} & \multirow[b]{2}{*}{$\begin{array}{l}\text { Sample } \\
\text { no. }{ }^{\mathrm{u}}\end{array}$} & \multirow[b]{2}{*}{ Raw material $(\%, \mathrm{vol} / \mathrm{vol})^{\mathrm{v}}$} & \multirow[b]{2}{*}{$\begin{array}{l}\text { Time } \\
\text { (days) }^{\mathrm{w}}\end{array}$} & \multirow[b]{2}{*}{$\begin{array}{l}\text { Length } \\
(\mathrm{m})^{\mathrm{x}}\end{array}$} & \multicolumn{10}{|c|}{ Physicochemical property ${ }^{y}$} \\
\hline & & & & & $\begin{array}{l}\mathrm{OM} \\
(\%)\end{array}$ & $\begin{array}{l}\mathrm{T}-\mathrm{N} \\
(\%)\end{array}$ & $\begin{array}{c}\mathrm{OM} / \\
\mathrm{N}\end{array}$ & $\begin{array}{l}\text { WC } \\
(\%)\end{array}$ & $\mathrm{pH}$ & CEC & $\begin{array}{c}\mathrm{EC} \\
(\mathrm{dS} / \mathrm{m})\end{array}$ & $\begin{array}{c}\mathrm{NH}_{4}^{+}- \\
\mathrm{N}^{\mathrm{z}}\end{array}$ & $\begin{array}{c}\mathrm{NO}_{3}^{-}- \\
\mathrm{N}^{\mathrm{z}}\end{array}$ & $\begin{array}{l}\mathrm{NH}_{4}^{+} / \\
\mathrm{NO}_{3}^{-}\end{array}$ \\
\hline Changsung & $2,3,6-10$ & $\begin{array}{l}\text { PM }(20)+\text { PoM }(20)+\text { SD }(30) \\
\text { +bark (10) + LW (20) }\end{array}$ & 45 & 70 & 55.9 & 2.18 & 25.6 & 36.2 & 8.1 & 39.7 & 3.0 & 1,939 & 1,354 & 1.58 \\
\hline Guman & $2-4,6-8$ & PM (25) + PoM (25) + Chaff (50) & 30 & 100 & 40.6 & 1.87 & 21.7 & 54.0 & 7.2 & 64.9 & 1.7 & 707 & 808 & 0.88 \\
\hline Iljuk & $2-4,6-10$ & $\mathrm{PM}(60)+\mathrm{CM}(10)+\mathrm{SD}(30)$ & 25 & 65 & 50.0 & 2.21 & 21.3 & 40.2 & 9.0 & 41.7 & 4.5 & 820 & 234 & 3.50 \\
\hline Shinong & $2-10$ & PoM (70) + SD (30) + Zeolite (Tr) & 40 & 50 & 57.3 & 3.04 & 18.8 & 61.6 & 7.6 & 64.9 & 4.4 & 11,350 & 607 & 19.46 \\
\hline Taenong & $2-11$ & $\begin{array}{l}\mathrm{PM}(10)+\mathrm{PoM}(20)+\mathrm{SD}(15) \\
+\mathrm{DOL}(55)\end{array}$ & 30 & 40 & 72.9 & 2.45 & 29.7 & 32.4 & 7.4 & 69.5 & 2.2 & 621 & 517 & 1.20 \\
\hline Taewon & $3,6-11$ & $\mathrm{PM}(50)+\mathrm{LW}(25)+\mathrm{SD}(25)$ & 40 & 70 & 67.6 & 2.12 & 31.9 & 40.6 & 7.0 & 107.8 & 4.7 & 2,632 & 1,178 & 2.23 \\
\hline
\end{tabular}

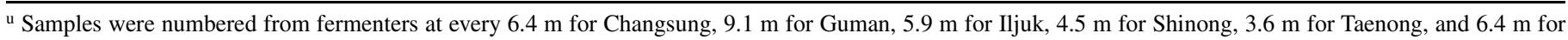
Taewon.

${ }^{v} \mathrm{PM}=$ pig manure, $\mathrm{PoM}=$ poultry manure, $\mathrm{SD}=$ sawdust, $\mathrm{LW}=$ livestock waste, $\mathrm{CM}=\mathrm{cow}$ manure, and $\mathrm{DOL}=\mathrm{dregs}$ of oil and lees; $\mathrm{Tr}=$ trace $(<0.1)$.

${ }^{\text {w }}$ Composting time.

x Fermenter length.

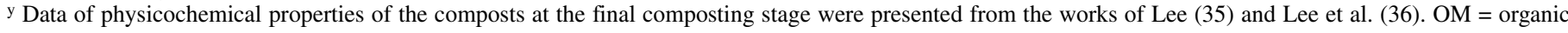
matter, T-N = total nitrogen, $\mathrm{WC}=$ water content, $\mathrm{CEC}=$ cation exchange capacity $\left(\mathrm{cmol}^{+} / \mathrm{kg}\right)$, and EC = electrical conductivity.

z Measured in milligrams/kilogram. 
(Whatman no. 1) and rinsed three times with distilled water. The collected mycelia (mg) without agars were dried at $60^{\circ} \mathrm{C}$ for 7 days and then weighed.

Biocontrol activity of CWE against $P$. capsici. To evaluate the biocontrol activity of the four selected CWE against $P$. capsici, seedling and plant assays were conducted. The seedlings and plants were root-drenched with CWE $(1 \mathrm{ml} / \mathrm{g}$ dry weight of potting mixture) from $10 \%$ (wt/vol) Iljuk-3, 10\% (wt/vol) Iljuk-7, $5 \%$ (wt/vol) Shinong-8, and 5\% (wt/vol) Shinong-9, or sterile distilled water (control). It should be noted that CWE from Shinong-8 and Shinong-9 were applied at a concentration of 5\% (wt/vol) due to growth inhibition of pepper seedlings by the concentration of $10 \%$ (wt/vol). For seedling assays, 2,000 zoospores of $P$. capsici per g dry weight of potting mixture were inoculated at $1 \mathrm{~cm}$ below the soil line near the seedlings 3 days after treatment. Disease incidence (\%) was evaluated 4 days after inoculation (DAI). For the plant assays, 25 zoospores per g dry weight of potting mixture were inoculated into four holes $(1 \mathrm{~cm}$ in diameter by $1 \mathrm{~cm}$ deep) around each plant. Disease severity was evaluated every day for 13 days on a scale of 0 (symptomless) to 5 (plant dead) as described by Kim et al. (31).

$\boldsymbol{P}$. capsici population in potting mixture. Five-week-old pepper plants prepared as described above were root-drenched with the four selected CWE $(1 \mathrm{ml} / \mathrm{g}$ dry weight of potting mixture) or sterile distilled water (control). Three days after treatment, 25 zoospores of $P$. capsici per g dry weight of potting mixture were inoculated in the potting mixture around each plant as mentioned above. Potting mixtures of the pots were collected three times (4 cm in depth) using a cork borer $(10 \mathrm{~mm}$ in diameter) around each plant $0,1,3,5$, and 7 DAI. The mixtures $(5 \mathrm{~g}$ each) were then placed in $10 \mathrm{ml}$ of sterile water and shaken at $160 \mathrm{rpm}$ at $28^{\circ} \mathrm{C}$ for $30 \mathrm{~min}$. The suspension was cultured at $28^{\circ} \mathrm{C}$ on PARPH medium (three plates per replicate) selective for Phytophthora spp. (51). Numbers of $P$. capsici colonies were counted 4 days after incubation and evaluated based on the dry weight of potting mixtures.

CWE sterilization and biocontrol activity against $P$. capsici. To evaluate abiotic biocontrol activity of CWE, the four selected CWE were either untreated, autoclaved at $121^{\circ} \mathrm{C}$ for $20 \mathrm{~min}$, or filtered through $0.22-\mu \mathrm{m}$ membrane filters (nylon, tissue culture filter unit; Nalgene, Rochester, NY). The untreated, autoclaved, or filtered CWE was evaluated for their ability to inhibit the zoospore germination (\%) and their biocontrol activity using the seedling and plant assays as described above.

ISR in pepper leaves against $\boldsymbol{P}$. capsici. For ISR analysis, the four selected CWE, DL- $\beta$-aminobutyric acid (BABA) (SigmaAldrich, St Louis, MO) (positive control), or sterile distilled water (negative control) were root-drenched to 5-week-old pepper plants $(1 \mathrm{ml} / \mathrm{g}$ and $500 \mu \mathrm{g} / \mathrm{g}$ dry weight of potting mixture for CWE and BABA, respectively) prepared as described above. At 3 days after treatment, mycelial plugs $(5 \mathrm{~mm}$ in diameter) of $P$. capsici grown on V8 juice medium or V8 juice agars (control) were inoculated on the third leaves of the plants, then incubated at $\approx 100 \%$ relative humidity at $28^{\circ} \mathrm{C}$. At 1 DAI, the agars were removed from the leaves and the plants were then placed at room temperature in a growth room with fluorescent light at $16 \mathrm{~h} /$ day. To assess the disease expression, the lesion diameters $(\mathrm{mm})$ were measured $72 \mathrm{~h}$ after inoculation by the following formula: [maximum lesion diameter $(\mathrm{mm})+$ minimum lesion diameter $(\mathrm{mm})] / 2$. To analyze the expression of pathogenesis-related $(P R)$ genes, the third leaves were sampled $0,24,48$, and $72 \mathrm{~h}$ after inoculation with $P$. capsici. Defense-related $\beta$-1,3-glucanase, chitinase, and peroxidase activities were also measured $72 \mathrm{~h}$ after inoculation. These tissues were frozen in liquid nitrogen until use.

Leaf tissue samples were homogenized using a mortar and a pestle, and total RNA was extracted using Trizol Reagent (Invitrogen, Carlsbad, CA) according to the manufacturer's instructions. For reverse-transcriptase polymerase chain reaction (RT-PCR), $0.5 \mu \mathrm{g}$ of total RNA was used for first-strand cDNA synthesis using Extend Reverse Transcriptase (Roche, Mannheim, Germany). Subsequently, $10 \%$ of the first-strand reactions were used for PCR. The sequences of the gene-specific primer pairs used in this study are listed in Table 2. PCR reactions were conducted in reaction mixtures with a final volume of $20 \mu \mathrm{l}$ that contained 1 unit of Taq polymerase (iNtRON, Seongnam, Korea), $250 \mu \mathrm{M}$ dNTPs, $50 \mathrm{ng}$ of each oligonucleotide primer, $1 \mu \mathrm{l}$ of cDNA, and $10 \times$ reaction buffer. Amplification of $18 \mathrm{~S}$ rRNA as an internal control (11) was used to adjust initial amounts of RT products from each sample in each PCR reaction. First, RT-PCR was conducted with $18 \mathrm{~S}$ rRNA primer; then, comparative amplification was performed with other oligonucleotide primer using equivalent total cDNA. Amplification of both $P R$ and $18 \mathrm{~S}$ rRNA genes was conducted in a MyCycler thermal cycler (BioRad, Hercules, CA) by subjecting the samples to the following conditions: denaturation for $5 \mathrm{~min}$ at $94^{\circ} \mathrm{C}$; followed by 35 cycles of $30 \mathrm{~s}$ at $94^{\circ} \mathrm{C}, 30 \mathrm{~s}$ at each $\mathrm{T}_{\mathrm{m}}$ and $1 \mathrm{~min}$ at $72^{\circ} \mathrm{C}$; with a final extension at $72^{\circ} \mathrm{C}$ for $8 \mathrm{~min}$. PCR products were separated by electrophoresis on $1.5 \%$ agarose gels in $1 \times$ Tris-acetate-EDTA buffer at $100 \mathrm{~V}$ for $90 \mathrm{~min}$. The experiments were conducted twice with three replicate plants each and produced similar results.

For the enzyme assays, $\beta$-1,3-glucanase activity was measured as the rate of reducing-sugar production from laminarin as a substrate according to the procedure described by Nelson et al. (41). Chitinase activity was assayed based on the colorimetric determination of $\mathrm{N}$-acetylglucosamine using chitin oligomers as a substrate as described by Abeles et al. (1). Peroxidase activity was assessed based on the change in absorbance at $470 \mathrm{~nm} / \mathrm{min} / \mathrm{mg}$ of protein using guaiacol as the hydrogen donor according to the method described by Hammerschmidt et al. (20). Protein contents were determined by the method described by Bradford (7) using bovine serum albumin as a standard.

$\mathrm{H}_{2} \mathrm{O}_{2}$ generation in pepper leaves against $P$. capsici. The CWE, plant, and treatment preparations as well as inoculation procedures and disease evaluation for assessment of $\mathrm{H}_{2} \mathrm{O}_{2}$ generation were conducted as described for the ISR tests. The third leaves of pepper plants inoculated with or without $P$. capsici were sampled $0,6,12,18$, and $24 \mathrm{~h}$ after inoculation. The $\mathrm{H}_{2} \mathrm{O}_{2}$ generation of the tissue samples was quantified based on the formation

TABLE 2. Sequences of gene-specific primers used for reverse-transcriptase polymerase chain reaction analysis

\begin{tabular}{|c|c|c|c|c|}
\hline Gene family & Specific class ${ }^{y}$ & Acc. no. ${ }^{\mathrm{z}}$ & 5' Primer & 3' Primer \\
\hline$C A B P R 1$ & PR protein 1 & AF053343 & 5'-GTAGGTGCTCTTGTTCTTCCC-3' & 5'-GTATGGCTTCTCGTTCACATAATTCC-3' \\
\hline$C A B G L U$ & $\beta$-1,3-Glucanase & AF227953 & 5'-TTCCCAATTCAATCTTCA AAC-3' & 5'-CGAGCAAAGGCGAATTTATCC-3' \\
\hline CAChi2 & Class II chitinase & AF091235 & 5'-CATTCATAACTGCAGCCAATTC-3' & 5'-GTCATCCAGAACGATATTGCTGT-3' \\
\hline CaPR-4 & PR protein 4 & AF244122 & 5'-GGCGCAGAGTGCTACGAAC-3' & 5'-AGTGTCCAATTGGTTAAACACG-3' \\
\hline CAPO1 & Peroxidase & AF442386 & 5'-CTATGGTATTAGGCCAAGGG-3' & 5'-GTCACAAGAACGGAATCACGG-3' \\
\hline CaPR-10 & PR protein 10 & AF244121 & 5'-CTTACTGACAAGTCCACAGCCT-3' & 5'-GCAGAAGCTTCAAATTTGCC-3' \\
\hline $18 \mathrm{~S}$ rRNA & $18 \mathrm{~S}$ rRNA & EF564281 & 5'-CGGTCCGCCTATGGTGAGCACCGGTCG-3' & 5'-TTCTTGGATTTATGAAAGACGAACAACTGC-3' \\
\hline
\end{tabular}

${ }^{\mathrm{y}} P R=$ pathogenesis-related.

$\mathrm{z}$ Accession numbers found at http://www.ncbi.hlm.nih.gov. 
of a ferric product-xylenol orange complex that was produced as a result of the reduction of $\mathrm{H}_{2} \mathrm{O}_{2}$ by ferrous ions in acid solution. These were detected by measuring the absorbance at $560 \mathrm{~nm}$ using a spectrophotometer (Amersham Biosciences Ultrospec, Cambridge, England) as described by Gay et al. (19). $\mathrm{H}_{2} \mathrm{O}_{2}$ measurements were expressed as relative values, with $100 \%$ corresponding to the maximum value of the water-treated control.

Lignification in pepper stems against $\boldsymbol{P}$. capsici. The CWE, plant, and treatment preparations as well as inoculation procedures and disease evaluation for lignification tests were conducted as described for the ISR tests. For lignification tests, pepper stems from the first, second, or third internodes (from bottom to top) were collected 3 DAI; then transversely sectioned $(\approx 200 \mu \mathrm{m}$ in thickness) using a microtome (model CUT5062; Slee Mainz, Mainz, Germany). The samples were stained in $0.02 \%$ toluidine blue for $1 \mathrm{~min}$; then rinsed twice with distilled water. Finally, the samples were stained for lignin with phloroglucinol (saturated solution in $2 \mathrm{M} \mathrm{HCl}$ ) for $2 \mathrm{~min}$ and the lignin accumulation was directly measured under a light microscope (4).

ISR in pepper and cucumber against fungal pathogens. To assess ISR of the four CWE against C. coccodes (pepper anthracnose pathogen) and $C$. orbiculare (cucumber anthracnose pathogen), 5-week-old pepper plants and 2-week-old cucumber (cv. Baeknokdadagi) seedlings were root drenched with the CWE, BABA (positive control) (500 and $100 \mu \mathrm{g} / \mathrm{g}$ dry weight of potting mixture for pepper and cucumber, respectively), or sterile distilled water (negative control). Pepper plants prepared as described above and cucumber seedlings prepared by the same procedures described for pepper were used. For conidial inocula, $C$. coccodes and $C$. orbiculare were cultured in potato dextrose agar (PDA) (Difco Laboratories, Detroit, MI) in the dark for 10 days at $28^{\circ} \mathrm{C}$. Conidia were harvested with sterile distilled water containing $0.03 \%$ ( vol/vol) Tween 20 and filtered through four layers of sterile cheesecloth to remove mycelial debris. Then, conidial concentrations of the pathogens were adjusted to $5 \times 10^{5}$ conidia/ml using a hemacytometer. For inoculation of pepper plants, 3 days after treatments, the pepper leaves were uniformly sprayed with conidial suspensions of $C$. coccodes using an atomizer. After inoculation, plants were placed in a dew chamber with $100 \%$ relative humidity at $28^{\circ} \mathrm{C}$ in the dark for $24 \mathrm{~h}$. Then, these inoculated plants were transferred to a growth room with fluorescent light at $16 \mathrm{~h} /$ day at room temperature. For inoculation of cucumber seedlings, the prepared conidia of $C$. orbiculare were inoculated on the seedlings 5 days after treatment and then placed under the same conditions as described above. Disease severity (\%), expressed as diseased leaf area per leaf, on the third leaves of pepper plants and the first leaves of cucumber seedlings was evaluated 5 DAI using Matrox inspector version 2.2 as described by Kwack et al. (34).

ISR in pepper and cucumber against bacterial pathogens. Pepper plants and cucumber seedlings treated with CWE, BABA, or sterile distilled water as described above were inoculated with $X$. campestris pv. vesicatoria (pepper bacterial spot pathogen) and $P$. syringae pv. lachrymans (cucumber bacterial angular leaf spot pathogen) to evaluate ISR of the CWE against pathogen infections. These bacterial pathogens were cultured in nutrient-broth yeast extract medium and tryptic soy broth (Difco Laboratories), respectively, in a rotary shaking incubator $(160 \mathrm{rpm})$ at $28^{\circ} \mathrm{C}$ for $48 \mathrm{~h}$. The bacterial cells were harvested by centrifugation at $5,000 \times g$ for $10 \mathrm{~min}$ and adjusted to $1 \times 10^{4} \mathrm{CFU} / \mathrm{ml}$ for $X$. campestris pv. vesicatoria and $1 \times 10^{8} \mathrm{CFU} / \mathrm{ml}$ for $P$. syringae $\mathrm{pv}$. lachrymans with $10 \mathrm{mM} \mathrm{MgSO}_{4}$ buffer. For inoculation of pepper plants, the suspension of $X$. campestris pv. vesicatoria was inoculated on the third leaves of the plants by infiltrating the intercellular space of the leaves using a plastic syringe 3 days after treatments (30). On the other hands, for inoculation of cucumber seedlings, the suspension of $P$. syringae pv. lachrymans was sprayed on the cucumber leaves 5 days after treatment using an atomizer. Then, these inoculated plants were placed in a dew chamber at $28^{\circ} \mathrm{C}$ with $100 \%$ relative humidity for $24 \mathrm{~h}$ and transferred to a growth room with fluorescent light at $16 \mathrm{~h} /$ day at room temperature. The third leaves of pepper plants and first leaves of cucumber seedlings were sampled $0,1,3$, and 5 DAI and macerated with a homogenizer. The diluted macerated leaves of pepper and cucumber were cultured on Tween B media (39) and Pseudomonas agar F (Difco Laboratories) (three plates per replicate), respectively, at $28^{\circ} \mathrm{C}$ for 3 days; then, numbers of bacterial colonies on the media were counted. Bacterial population was determined based on the number of cells per gram dry weight of leaf tissues.

Statistical analysis. All experiments were established as a completely randomized design and conducted twice with three replicates each for the germination and germ tube tests, four replicates each for the mycelial growth tests, three replicates of eight seedlings each for the seedling assays, 10 replicates each for the plant assays, three replicates each for the $P$. capsici population tests, four replicates each for the ISR tests to P. capsici and $\mathrm{H}_{2} \mathrm{O}_{2}$ generation tests, three replicates each for the lignification tests, 10 replicates each for ISR tests to fungal pathogens, and four or three replicates each for ISR tests to bacterial pathogens. Statistical analysis of the data was conducted using the Statistical Analysis Systems (SAS Institute, Cary, NC). Data from repeated experiments in each test, except ISR tests to fungal pathogens, were pooled after confirming homogeneity of variances with Levene's test (38) and were further statistically analyzed. For analysis of ordinal data such as diseases severity and $\mathrm{H}_{2} \mathrm{O}_{2}$ generation, a nonparametric analysis was used based on ranks of the data. Multiple comparisons based on the least significant difference (LSD) were also conducted to determine differences in mean ranks. On the other hand, the percent data of germination, disease incidence, and disease severity were statistically analyzed after arcsine square-root transformation; population data were analyzed after $\log$ transformation. Analysis of variance was determined using the GLM procedures and the means were separated using the LSD at $P<0.05$.

\section{RESULTS}

Effects of CWE on $\boldsymbol{P}$. capsici germination and growth. Of 47 CWE, 19 significantly $(P<0.05)$ inhibited zoospore germination (data not shown). Among these, nine CWE came from the Shinong compost facility; five from the Iljuk compost facility; three from the Changsung compost facility; and two from the Taenong compost facility. Therefore, four CWE from Iljuk-3, Iljuk-7, Shinong-8, and Shinong-9 were finally selected for further study. These selected CWE significantly $(P<0.05)$ inhibited the germination rate and germ tube length as well as the mycelial growth of $P$. capsici compared with the untreated controls (Table 3). Specifically, the reduction in $P$. capsici germination in response to CWE treatments was 76.7 to $91.2 \%$ while the reduction in germ tube length was 59.4 to $80.2 \%$ and mycelia growth was reduced by 57.1 to $72.2 \%$ compared with the untreated controls.

Effects of CWE on disease suppression and $P$. capsici population. In the seedling assay, the CWE from Iljuk-3, Iljuk-7, Shinong-8, and Shinong-9 significantly $(P<0.05)$ suppressed disease incidence compared with the control (Table 4). In the plant assays, all CWE also significantly $(P<0.05)$ reduced disease severity compared with the control (Table 4$)$. With the exception of Iljuk-3 at 1 DAI, all tested CWE significantly $(P<$ $0.05)$ reduced the population of $P$. capsici in potting mixtures of 5-week-old pepper plants at 1 to 7 DAI compared with the untreated controls (Table 5). However, the CWE did not have a significant effect on the pathogen population at 0 DAI. Overall, all tested CWE significantly $(P<0.05)$ reduced the pathogen population over time; however, untreated controls gradually 
increased the population. For example, CWE from Shinong-9 reduced the pathogen population from $\log 1.61$ (40.7 CFU) at 0 DAI to $\log 1.03$ (10.7 CFU) at 7 DAI. However, the untreated control enhanced the population from $\log 1.60$ (39.8 CFU) at 0 DAI to $\log 1.82$ (66.1 CFU) at 7 DAI (Table 5).

TABLE 3. Inhibition of germination, germ tube, and mycelial growth of Phytophthora capsici by water extracts of composts (CWE), Iljuk-3 (10\%, wt/vol), Iljuk-7 (10\%, wt/vol), Shinong-8 (10\%, wt/vol), and Shinong-9 (10\%, $\mathrm{wt} / \mathrm{vol}$ )

\begin{tabular}{lccc}
\hline Treatment & Germination $(\%)^{\mathrm{z}}$ & Germ tube $(\mu \mathrm{m})$ & Mycelial dry wt $(\mathrm{mg})$ \\
\hline Control & $86.1 \pm 1.2 \mathrm{a}$ & $81.2 \pm 2.8 \mathrm{a}$ & $82.8 \pm 4.2 \mathrm{a}$ \\
Iljuk-3 & $20.1 \pm 0.9 \mathrm{~b}$ & $32.9 \pm 2.6 \mathrm{~b}$ & $27.8 \pm 6.2 \mathrm{~b}$ \\
Iljuk-7 & $14.7 \pm 2.0 \mathrm{~b}$ & $33.0 \pm 2.9 \mathrm{~b}$ & $35.5 \pm 8.3 \mathrm{~b}$ \\
Shinong-8 & $15.0 \pm 3.7 \mathrm{~b}$ & $16.4 \pm 2.6 \mathrm{~d}$ & $23.0 \pm 6.7 \mathrm{~b}$ \\
Shinong-9 & $7.6 \pm 2.1 \mathrm{c}$ & $24.7 \pm 2.4 \mathrm{c}$ & $32.6 \pm 6.9 \mathrm{~b}$
\end{tabular}

${ }^{\mathrm{z}}$ Germination rate and germ tube length of encysted zoospores in $10 \%$ (wt/vol) CWE or sterile distilled water (control) were evaluated based on $\approx 100$ zoospores/observation (three times per replicate) after incubation for $2 \mathrm{~h}$ at $28^{\circ} \mathrm{C}$. Mycelial dry weights were determined 10 days after incubation at $28^{\circ} \mathrm{C}$ in $20 \mathrm{ml}$ of a $1: 1(\mathrm{vol} / \mathrm{vol})$ mixture of V8 juice broth and $20 \%$ (wt/vol) CWE or sterile distilled water. Values are the means of six or eight replications of germination and germ tube growth or mycelial growth. Means \pm standard errors followed by the same letters are not significantly different according to the least significant difference test at $P<0.05$. Arcsine square root-transformed data were used for statistical analysis of the germination; however, untransformed data are presented.

TABLE 4. Disease incidence and severity caused by Phytophthora capsici on pepper (cv. Nockwang) seedlings and plants treated with water extracts of composts (CWE), Iljuk-3 (10\%, wt/vol), Iljuk-7 (10\%, wt/vol), Shinong-8 $(5 \%, \mathrm{wt} / \mathrm{vol})$, and Shinong-9 (5\%, wt/vol)

\begin{tabular}{lcccc}
\hline & \multicolumn{2}{c}{ Seedling assay $^{\mathrm{y}}$} & & \multicolumn{2}{c}{ Plant assay (disease severity) } \\
\cline { 2 - 3 } \cline { 5 - 5 } Treatment & Disease incidence $(\%)$ & & Median & Rank \\
\hline Control & $77.1 \pm 3.3 \mathrm{a}$ & & 3.5 & $71.2 \pm 3.6 \mathrm{a}$ \\
Iljuk-3 & $45.8 \pm 6.0 \mathrm{bc}$ & & 2.5 & $43.0 \pm 6.1 \mathrm{~b}$ \\
Iljuk-7 & $45.8 \pm 4.6 \mathrm{bc}$ & & 3.0 & $52.7 \pm 7.6 \mathrm{~b}$ \\
Shinong-8 & $60.4 \pm 5.2 \mathrm{~b}$ & & 2.5 & $40.1 \pm 4.6 \mathrm{~b}$ \\
Shinong-9 & $39.6 \pm 3.3 \mathrm{c}$ & & 2.5 & $40.8 \pm 5.9 \mathrm{~b}$ \\
\hline
\end{tabular}

${ }^{\mathrm{y}}$ Two-week-old seedlings root-drenched with CWE or sterile distilled water (control) were inoculated with 2,000 zoospores of $P$. capsici per g dry weight of potting mixture 3 days after treatment. Disease incidence was determined 4 days after inoculation. Values shown are the means of six replications with eight seedlings each. Means \pm standard errors followed by the same letters are not significantly different according to the least significant difference (LSD) test at $P<0.05$. Arcsine square root-transformed data were used for statistical analysis of the disease incidence; however, untransformed data are presented.

${ }^{\text {z }}$ Five-week-old plants root-drenched with CWE or sterile distilled water (control) were inoculated with 25 zoospores of $P$. capsici per g dry weight of potting mixture 3 days after treatment. Disease severity was evaluated on a scale of 0 (symptomless) to 5 (plants dead) 13 days after inoculation. Values are the mean ranks of 20 replications. Mean ranks \pm standard errors followed by the same letter within a column are not significantly different according to the nonparametric rank test followed by the LSD at $P<0.05$.
Effects of CWE sterilization on the biocontrol activity of $\boldsymbol{P}$. capsici. All tested CWE significantly $(P<0.05)$ reduced zoospore germination, disease incidence on pepper seedlings, and disease severity on plants compared with the untreated controls (Table 6). However, there were no significant $(P>0.05)$ differences between treatments of untreated, autoclaved, and filtered CWE in zoospore germination, disease incidence, and disease severity (Table 6). There were also no significant $(P>0.05)$ CWE-treatment interactions in zoospore germination, disease incidence, and disease severity.

Effects of CWE on ISR in pepper leaves against $\boldsymbol{P}$. capsici. Treatments with CWE from Iljuk-3, Iljuk-7, Shinong-8, Shinong9 , and BABA (positive control) significantly $(P<0.05)$ reduced the lesion diameters on the third leaves of the plants compared with the water-treated control when the treatments were drenched into roots of the plants (Fig. 1). The reductions in the lesion diameters by CWE were 30.0 to $55.1 \%$ compared with the watertreated control. On the other hand, BABA produced the lowest lesion diameters, with a $75.2 \%$ reduction compared with the water-treated control (Fig. 1). However, no disease symptoms were observed in the treatments when pepper leaves were not inoculated by the pathogen (Fig. 1). Expression of the $P R$ genes $C A B P R 1$ (basic $P R$ protein 1), CABGLU ( $\beta$-1,3-glucanase), CAChi2 (class II chitinase), CaPR-4 (PR protein 4), CAPOI (peroxidase), or $C a P R-10$ ( $P R$ protein 10$)$ was detected in certain treatments with CWE and BABA (positive control) compared with the water-treated negative controls. However, expression of $P R$ genes $C a P R-4$ and $C A P O 1$ was not detected in the treatments of Iljuk-7 and Shinong-8, respectively (Fig. 2). In addition, un-

TABLE 6. Zoospore germination, disease incidence (DI), and disease severity (DS) caused by Phytophthora capsici on pepper (cv. Nockwang) seedlings and plants treated with untreated, autoclaved, or filtered water extracts of composts (CWE), Iljuk-3, Iljuk-7, Shinong-8, and Shinong-9

\begin{tabular}{lccccc}
\hline & & Seedling assay $^{\mathrm{y}}$ & & \multicolumn{2}{c}{ Plant assay (DS) } \\
\cline { 3 - 4 } \cline { 5 - 6 } Factor, level & Germination (\%) & DI (\%) & & Median & Rank \\
\hline CWE & & & & & \\
Control & $85.9 \pm 0.9 \mathrm{a}$ & $81.3 \pm 1.5 \mathrm{a}$ & & 3.0 & $112.3 \pm 4.2 \mathrm{a}$ \\
Iljuk-3 & $16.0 \pm 1.3 \mathrm{bc}$ & $51.4 \pm 2.0 \mathrm{~b}$ & & 2.0 & $65.1 \pm 7.5 \mathrm{~b}$ \\
Iljuk-7 & $17.9 \pm 1.1 \mathrm{~b}$ & $50.0 \pm 1.8 \mathrm{~b}$ & & 3.0 & $74.7 \pm 7.9 \mathrm{~b}$ \\
Shinong-8 & $15.5 \pm 1.1 \mathrm{bc}$ & $47.2 \pm 2.4 \mathrm{bc}$ & 2.0 & $66.4 \pm 6.0 \mathrm{~b}$ \\
Shinong-9 & $14.1 \pm 0.8 \mathrm{c}$ & $44.4 \pm 1.8 \mathrm{c}$ & 2.0 & $59.0 \pm 7.2 \mathrm{~b}$ \\
Treatment & & & & \\
$\quad$ Unsterilized & $28.8 \pm 5.2 \mathrm{a}$ & $55.8 \pm 2.9 \mathrm{a}$ & & 3.0 & $76.1 \pm 5.5 \mathrm{a}$ \\
Autoclaved & $31.8 \pm 5.3 \mathrm{a}$ & $52.9 \pm 3.2 \mathrm{a}$ & & 3.0 & $72.7 \pm 6.1 \mathrm{a}$ \\
Filtered & $29.0 \pm 5.3 \mathrm{a}$ & $55.8 \pm 2.6 \mathrm{a}$ & 3.0 & $77.6 \pm 5.8 \mathrm{a}$ \\
\hline
\end{tabular}

${ }^{y}$ Means \pm standard errors followed by the same letters are not significantly different according to the least significant difference (LSD) test at $P<0.05$. Arcsine square root-transformed data were used for statistical analysis of germination and disease incidence; however, untransformed data are presented.

${ }^{\mathrm{z}}$ Mean ranks \pm standard errors followed by the same letter within a column are not significantly different according to the nonparametric rank test followed by the LSD at $P<0.05$.

TABLE 5. Temporal changes in Phytophthora capsici population on pepper (cv. Nockwang) plants treated with water extracts of composts (CWE), Iljuk-3 (10\%, $\mathrm{wt} / \mathrm{vol})$, Iljuk-7 (10\%, wt/vol), Shinong-8 (5\%, wt/vol), and Shinong-9 (5\%, wt/vol)

\begin{tabular}{|c|c|c|c|c|c|}
\hline \multirow[b]{2}{*}{ Treatment } & \multicolumn{5}{|c|}{ P. capsici population ( $\log \mathrm{CFU} / \mathrm{g}$ dry weight of potting mixture $)^{\mathrm{z}}$} \\
\hline & 0 DAI & $1 \mathrm{DAI}$ & 3 DAI & 5 DAI & 7 DAI \\
\hline Control & $1.60 \pm 0.01 \mathrm{bB}$ & $1.59 \pm 0.02 \mathrm{aB}$ & $1.63 \pm 0.03 \mathrm{aB}$ & $1.77 \pm 0.03 \mathrm{aA}$ & $1.82 \pm 0.02 \mathrm{aA}$ \\
\hline Iljuk-3 & $1.54 \pm 0.02 \mathrm{cA}$ & $1.55 \pm 0.02 \mathrm{abA}$ & $1.46 \pm 0.01 \mathrm{bB}$ & $1.31 \pm 0.02 \mathrm{bC}$ & $1.25 \pm 0.01 \mathrm{bD}$ \\
\hline Iljuk-7 & $1.58 \pm 0.01 \mathrm{bcA}$ & $1.50 \pm 0.01 \mathrm{cB}$ & $1.41 \pm 0.01 \mathrm{bcC}$ & $1.32 \pm 0.03 \mathrm{bD}$ & $1.27 \pm 0.03 \mathrm{bD}$ \\
\hline Shinong-8 & $1.67 \pm 0.01 \mathrm{aA}$ & $1.52 \pm 0.01 \mathrm{bcB}$ & $1.34 \pm 0.01 \mathrm{dC}$ & $1.09 \pm 0.01 \mathrm{cD}$ & $1.06 \pm 0.01 \mathrm{cE}$ \\
\hline Shinong-9 & $1.61 \pm 0.02 \mathrm{bA}$ & $1.41 \pm 0.01 \mathrm{~dB}$ & $1.38 \pm 0.01 \mathrm{cdB}$ & $1.05 \pm 0.01 \mathrm{cC}$ & $1.03 \pm 0.01 \mathrm{cC}$ \\
\hline
\end{tabular}

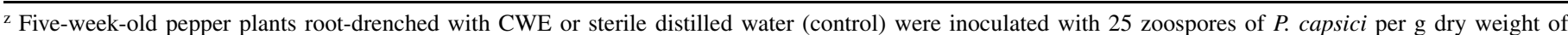
potting mixture 3 days after treatment. The population of $P$. capsici was evaluated on PARPH medium selective for Phytophthora spp. at various days after inoculation (DAI). Values are means of six replications. Means \pm standard errors followed by the same small or capital letters did not differ significantly between treatments at a given DAI or between DAIs at a given treatment according to the least significant difference test at $P<0.05$. 
inoculated pepper leaves did not express the $P R$ genes regardless of the treatments. Increased expression of genes encoding $\beta-1,3-$ glucanase, class II chitinase, and peroxidase in response to the CWE and BABA treatments was also observed in quantitative assays for these enzymes (Fig. 3). The activities of $\beta-1,3-$ glucanase, chitinase, and peroxidase were significantly $(P<0.05)$ enhanced in the third leaves of plants treated with all CWE or BABA, compared with the water-treated controls, when the leaves were inoculated by $P$. capsici. However, these enzyme activities did not differ among the treatments in uninoculated pepper leaves (Fig. 3).

The results of a xylenol orange assay of pepper leaves revealed that the generation of $\mathrm{H}_{2} \mathrm{O}_{2}$ was enhanced greatly in inoculated leaves of plants root-drenched with CWE and BABA at 6 to $24 \mathrm{~h}$ after inoculation with $P$. capsici, compared with uninoculated leaves (Fig. 4). Moreover, CWE and BABA treatments significantly $(P<0.05)$ induced higher levels of $\mathrm{H}_{2} \mathrm{O}_{2}$ in leaves at 6 to $12 \mathrm{~h}$ after inoculation with $P$. capsici than the water treatment;

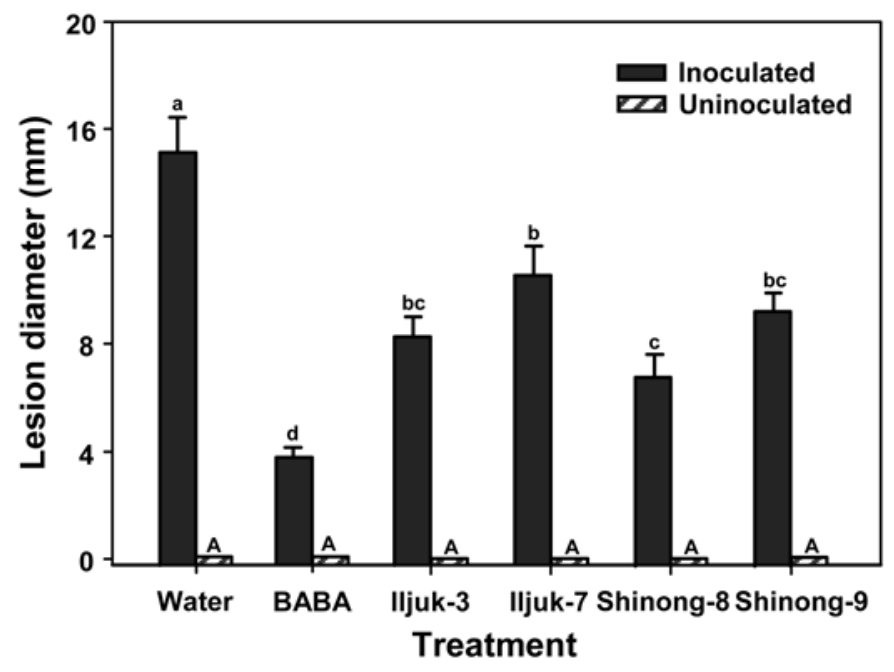

Fig. 1. Lesion diameters on the third leaves of 5-week-old pepper plants after treatment with water extracts of composts, Iljuk-3 (10\%, wt/vol), Iljuk-7 (10\%, wt/vol), Shinong-8 (5\%, wt/vol), Shinong-9 (5\%, wt/vol), DL- $\beta$-amino butyric acid (BABA, positive control), or sterile distilled water (negative control) 3 days after inoculation with or without Phytophthora capsici. Third leaves of the pepper plants root-drenched with the treatments were inoculated with or without the pathogen 3 days after treatment. Each bar represents the standard error of the mean of eight replications. Different small or capital letters on the bars indicate significant differences between treatments at $P<0.05$. thereafter, these levels decreased gradually. However, the $\mathrm{H}_{2} \mathrm{O}_{2}$ generation did not differ in uninoculated leaves over time regardless of the treatments (Fig. 4).

Effects of CWE on lignification in pepper stems against $\boldsymbol{P}$. capsici. $P$. capsici enhanced lignin accumulation in the stems of plants root-treated with CWE and BABA but not in those of the water-treated control when compared with uninoculated leaves (Fig. 5). The CWE and BABA treatments significantly $(P<0.05)$ accumulated lignin in the stems of inoculated plants compared with the water treatments. Moreover, the lignin accumulation was the highest in the first internode, followed by the second and third internodes, regardless of the treatments or inoculation. However, the lignin levels in the stems did not differ among treatments when the leaves were not inoculated with P. capsici (Fig. 5).

Effects of CWE on ISR in pepper and cucumber against fungal and bacterial pathogens. Treatments with CWE from Iljuk-3, Iljuk-7, Shinong-8, Shinong-9, and BABA significantly $(P<0.05)$ reduced anthracnose severity caused by $C$. coccodes in the third leaves of pepper plants compared with the water-treated controls when the treatments were drenched into roots of the plants (Fig. 6A). Disease severity was reduced 27.7 to $40.7 \%$ in experiment 1 and 34.3 to $65.7 \%$ in experiment 2 by CWE compared with the water treatments. On the other hand, BABA produced the lowest disease severity with 89.8 and $84.1 \%$ reduction in experiments 1 and 2, respectively, compared with the water treatments (Fig. 6A). Similar results were observed in cucumber seedlings root-drenched with the treatments (Fig. 6B). The CWE and BABA treatments significantly $(P<0.05)$ reduced anthracnose severity caused by $C$. orbiculare in the first leaves of cucumber seedlings compared with the water-treated controls. The disease severity was reduced 47.1 to $73.8 \%$ in experiment 1 and 40.7 to $64.5 \%$ in experiment 2 by CWE compared with the water treatments. On the other hand, BABA produced one of the lowest disease severities, with 67.8 and $85.4 \%$ reduction in experiments 1 and 2 , respectively, compared with the water treatments (Fig. 6B). However, disease symptoms were not observed when pepper and cucumber leaves were not inoculated with the pathogens.

The tested CWE generally did not influence the population of $X$. campestris pv. vesicatoria on the third leaves of pepper plants and $P$. syringae pv. lachrymans on the first leaves of cucumber seedlings compared with water-treated controls (Table 7). Overall, all treatments significantly $(P<0.05)$ increased the bacterial population over time. However, the CWE treatments did not significantly $(P>0.05)$ reduce the bacterial population at 0 to 5 DAI, except Iljuk-3 on pepper 0 DAI compared with the water-
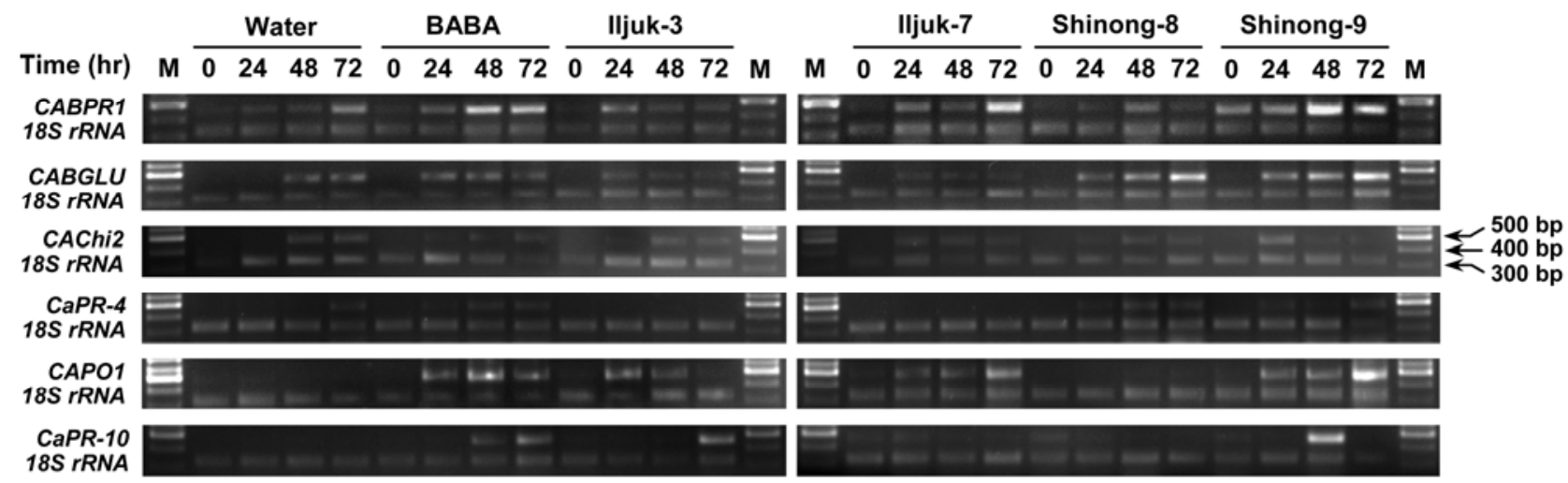

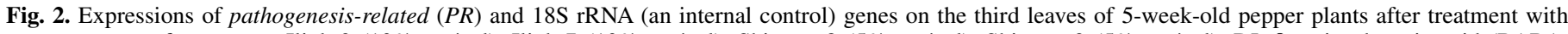

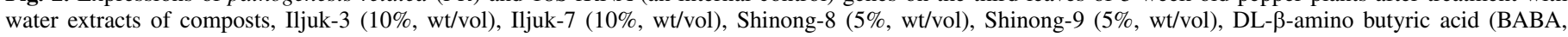

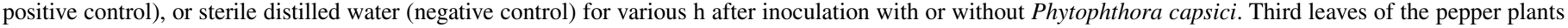

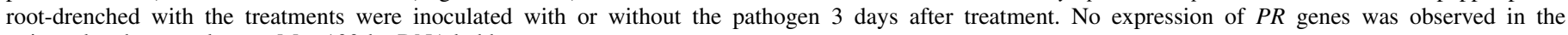
uninoculated pepper leaves. $\mathrm{M}=100$-bp DNA ladder. 
treated controls. BABA treatment significantly $(P<0.05)$ inhibited the bacterial population on pepper 3 and 5 DAI and on cucumber 5 DAI compared with the water-treated controls (Table 7). However, the bacteria were not detected when pepper and cucumber leaves were inoculated with $10 \mathrm{mM} \mathrm{MgSO}_{4}$ buffer (uninoculated control).

\section{DISCUSSION}

Composts and CWE have been used to control various soilborne and airborne plant pathogens; therefore, we investigated

A

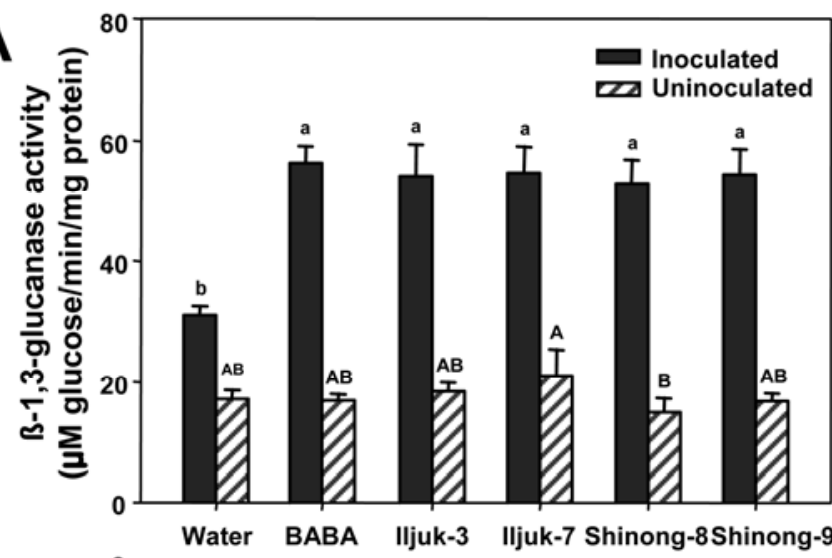

B
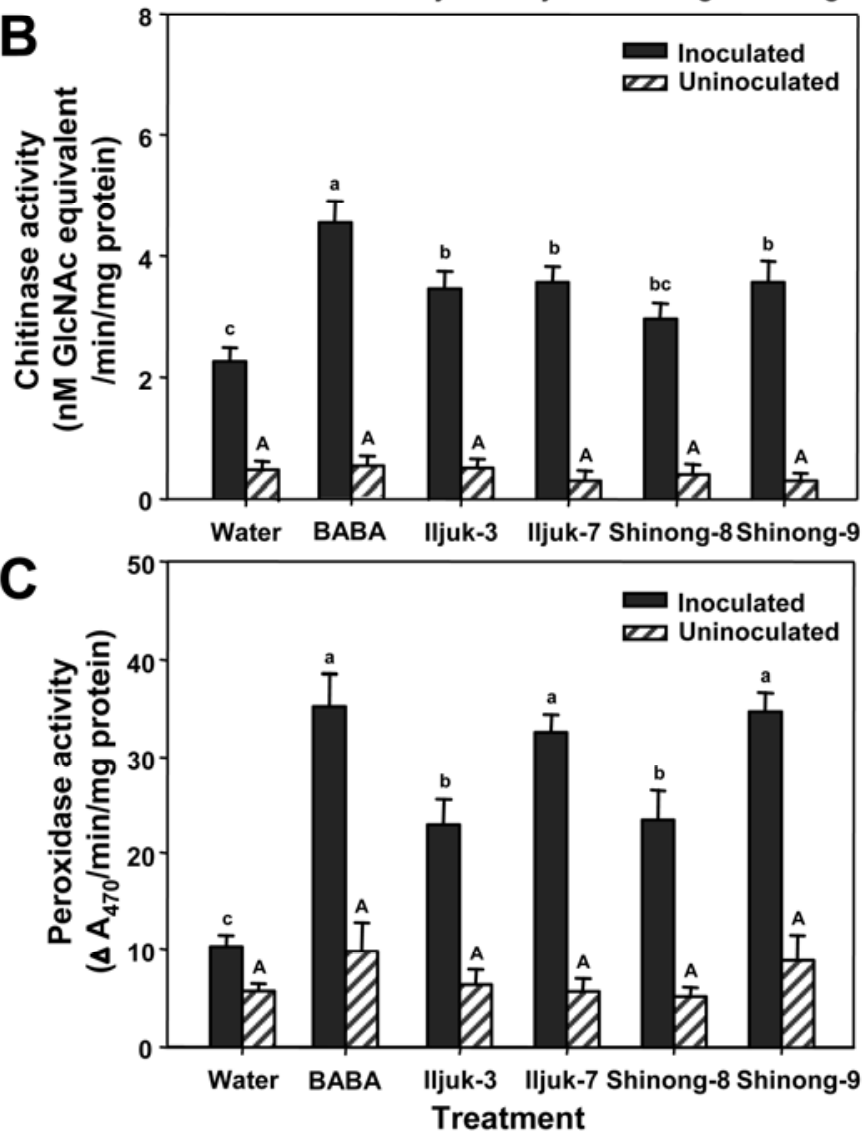

Fig. 3. A, $\beta-1,3-G l u c a n a s e ; ~ B$, chitinase; and $\mathbf{C}$, peroxidase activities on the third leaves of 5-week-old pepper plants after treatment with water extracts of composts, Iljuk-3 (10\%, wt/vol), Iljuk-7 (10\%, wt/vol), Shinong-8 (5\%, $\mathrm{wt} / \mathrm{vol})$, Shinong-9 (5\%, wt/vol), DL- $\beta$-amino butyric acid (BABA, positive control), or sterile distilled water (negative control) 3 days after inoculation with or without Phytophthora capsici. Third leaves of the pepper plants rootdrenched with the treatments were inoculated with or without the pathogen 3 days after treatment. Each bar represents the standard error of the mean of eight replications. Different small or capital letters on the bars indicate significant differences between treatments at $P<0.05$. the CWE of composts from commercial compost facilities to determine whether they were useful for the control of root and foliar infection by $P$. capsici in pepper plants. The results demonstrated that the CWE tested in this study effectively inhibited $P$.

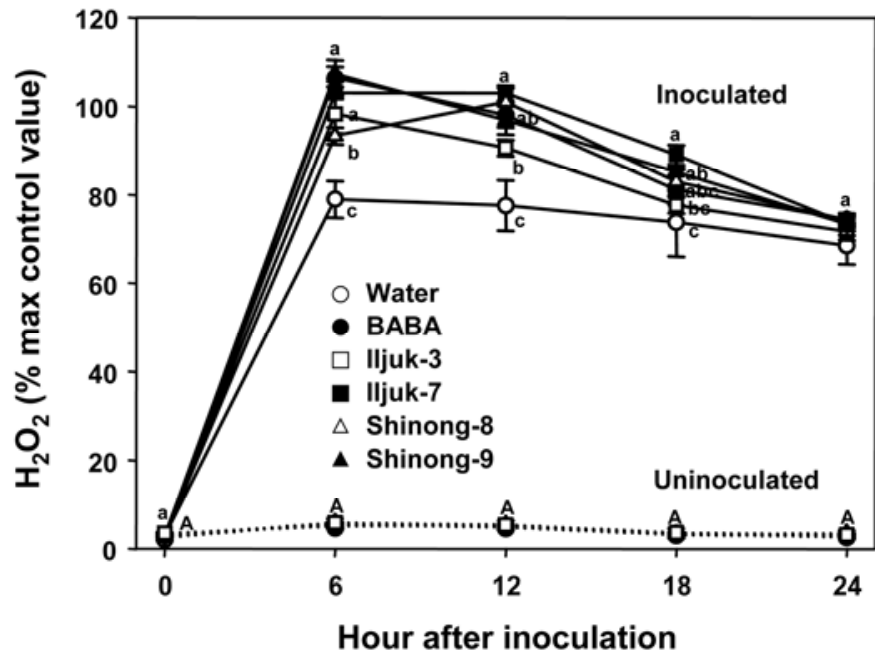

Fig. 4. Quantification of $\mathrm{H}_{2} \mathrm{O}_{2}$ generation of the third leaves of 5-week-old pepper plants after treatment with water extracts of composts, Iljuk-3 (10\%, wt/vol), Iljuk-7 (10\%, wt/vol), Shinong-8 (5\%, wt/vol), Shinong-9 (5\%, $\mathrm{wt} / \mathrm{vol}$ ), DL- $\beta$-amino butyric acid (BABA, positive control), or sterile distilled water (negative control) various hours after inoculation with or without Phytophthora capsici. Third leaves of pepper plants root-drenched with the treatments were inoculated with or without the pathogen 3 days after treatment. Each bar represents the standard error of the mean of eight replications. Different small or capital letters at a given time indicate significant differences between treatments at $P<0.05$. Lesion lengths of inoculated plants by the treatments were as follows: water $=13.8, \mathrm{BABA}=$ 3.5 , Iljuk-3 $=7.2$, Ikjuk-7 $=6.6$, Shinong- $8=6.3$, and Shinong- $9=6.9 \mathrm{~mm}$ (least significant difference at $P<0.05=0.9 \mathrm{~mm}$ ). No lesions were observed in the uninoculated pepper leaves.

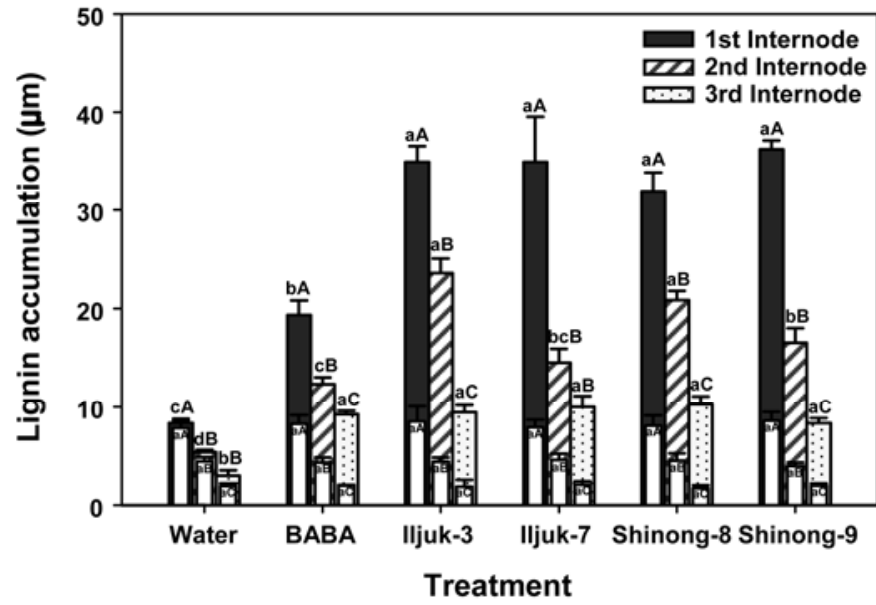

Fig. 5. Lignin accumulation in the first, second, and third internodes of stems of 5-week-old pepper plants treated with water extracts of composts, Iljuk-3 (10\%, wt/vol), Iljuk-7 (10\%, wt/vol), Shinong-8 (5\%, wt/vol), Shinong-9 (5\%, $\mathrm{wt} / \mathrm{vol}$ ), DL- $\beta$-amino butyric acid (BABA, positive control), or sterile distilled water (negative control) 3 days after inoculation with or without Phytophthora capsici. Third leaves of pepper plants root-drenched with the treatment were inoculated with (marked bars) or without (white bars within marked bars) the pathogen 3 days after treatment. Each bar represents the standard error of the mean of six replications. Different small or capital letters on the bars indicate significant differences between treatments at a given internode or between internodes at a given treatment at $P<0.05$. Lesion lengths of inoculated plants by the treatments were as follows: water $=15.3, \mathrm{BABA}=3.2$, Iljuk-3 $=6.6$, Ikjuk-7 $=7.1$, Shinong- $8=6.4$, and Shinong-9 $=7.8 \mathrm{~mm}$ (least significant difference at $P<0.05=1.0 \mathrm{~mm}$ ). No lesions were observed in the uninoculated pepper leaves. 
capsici development and reduced the pathogen infections in the roots and leaves of the plants.

We found that the tested CWE had direct effects on zoospore germination, germ tube elongation, and mycelial growth of $P$. capsici. The composts or their extracts have been well known to inhibit fungal growth or propagule germination by certain chemicals and enzymes, or to increase plant defense, thereby leading to disease suppression $(2,13,16,56,57)$. In some cases, composts or their extracts play a role in changes of the microbial activity and diversity that could result in the suppression of various soilborne diseases $(17,29)$. In addition to the in vitro inhibition of $P$. capsici observed in this study, CWE treatments also reduced the population of $P$. capsici in the rhizosphere of pepper plants. Palloix et al. (42) reported that pathogen infection was related to zoospore density and that the population had to persist in soil for disease occurrence. Therefore, reduction of the population of $P$. capsici in rhizosphere soil in response to treatment with CWE, in addition to inhibition of the pathogen development, may result in reduction of the disease incidence and severity.

In the present study, $P$. capsici germination and the incidence and severity of disease were reduced by treatment with the untreated CWE; however, these effects did not differ from the effects of treatments with autoclaved or filtered CWE. These results imply that the suppressive effects of CWE may be due to a heat-stable chemical factor(s) in CWE but not a biological factor(s). This type of disease suppression by chemical compounds in composts or their water extracts has been described in previous studies. For example, Cronin et al. (13) observed that water extract of the slurries of spent mushroom substrate inhibited in vitro germination of the conidia of the apple scab pathogen, Venturia inaequalis. On the other hand, Kim et al. (28) found that the elements $\mathrm{K}$ and $\mathrm{Mg}$ in compost and soil amendment-treated soils were related to increased soil microbial activity, which may have affected the root and crown rot of bell pepper caused by $P$. capsici.

It is interesting to recognize that, in addition to direct suppression of the development of $P$. capsici, CWE also led to indirect suppression of the pathogen in the leaves through ISR when it was applied to the roots of pepper plants. Moreover, the CWE tested in this study suppressed infection of other fungal pathogens such as $C$. coccodes in pepper leaves and $C$. orbiculare in cucumber leaves through ISR; however, it failed to inhibit the growth of other bacterial pathogens, such as $X$. campestris pv. vesicatoria in pepper leaves and $P$. syringae pv. lachrymans in cucumber leaves. These results indicate that ISR induced by the CWE may act differently against fungal and bacterial pathogens. Moreover, these current results imply that these CWE generated ISR to produce broad-spectrum protection not only against infection by $P$. capsici on pepper but also against infection by $C$. coccodes on pepper and $C$. orbiculare on cucumber. Previously, a similar phenomenon regarding broad-spectrum protection was observed mainly in PGPR-mediated ISR but a little in compost or their extract-mediated ISR $(33,45)$. Nevertheless, studies on indirect suppression of foliar diseases through ISR by composts or their extracts have been attempted by several researchers. For example, Vallad et al. (52) reported that composted forms of paper mill residuals reduced bacterial speck caused by $P$. syringae pv. tomato in Arabidopsis thaliana via ISR. Kavroulakis et al. (25) also found that a compost mix made from grape marc wastes and extracted olive press cake elicited local and systemic resistance in tomato against a root-infecting fungal pathogen, Fusarium oxysporum f. sp. radicus-lycopersici. Based on these results, the CWE tested in this study could be another CWE capable of ISR against infection by the oomycete pathogen, $P$. capsici, and anthracnose pathogens $C$. coccodes and $C$. orbiculare on pepper and cucumber.

Molecular, biochemical, and physiological evidence of $P R$ gene expression demonstrated that root treatment of CWE tested in this study was effective to establish the ISR in leaves of pepper plants. Specifically, the CWE enhanced the expression of the $P R$ genes $C A B P R 1$ (basic $P R$ protein 1), CABGLU ( $\beta$-1,3-glucanase), $C A C h i 2$ (class II chitinase), $C a P R-4$ ( $P R$ protein 4 ), CAPOl (peroxidase), or $C a P R-10$ ( $P R$ protein 10) as well as enzyme activities, including $\beta$-1,3-glucanase, chitinase, and peroxidase, which resulted in enhanced plant defense against $P$. capsici infection in pepper plants. Previously, Lee and Hwang (37) demonstrated that the induction of defense-related genes such as $C A B P R 1$ was essential for establishing local and systemic acquired resistance (SAR) in pepper plants. Expression of the PRl gene has been known to be triggered through a salicylicacid-dependent signaling pathway and to be related to SAR (8). In addition, the elevated levels of $P R 2, P R 3$, and peroxidase gene expression were related to increased activities of $\beta$-1,3-glucanase, chitinase, and peroxidase as key enzymes in plant defense. These defense responses of pepper plants may be induced more rapidly and strongly than in controls due to the induction of $P R$ gene expression in leaves infected by $P$. capsici, as observed in the Arabidopsis-Pseudomonas system by Verhagen et al. (54). Moreover, the CWE tested in this study enhanced the chemical and structural defenses of the pepper plants, including hydrogen
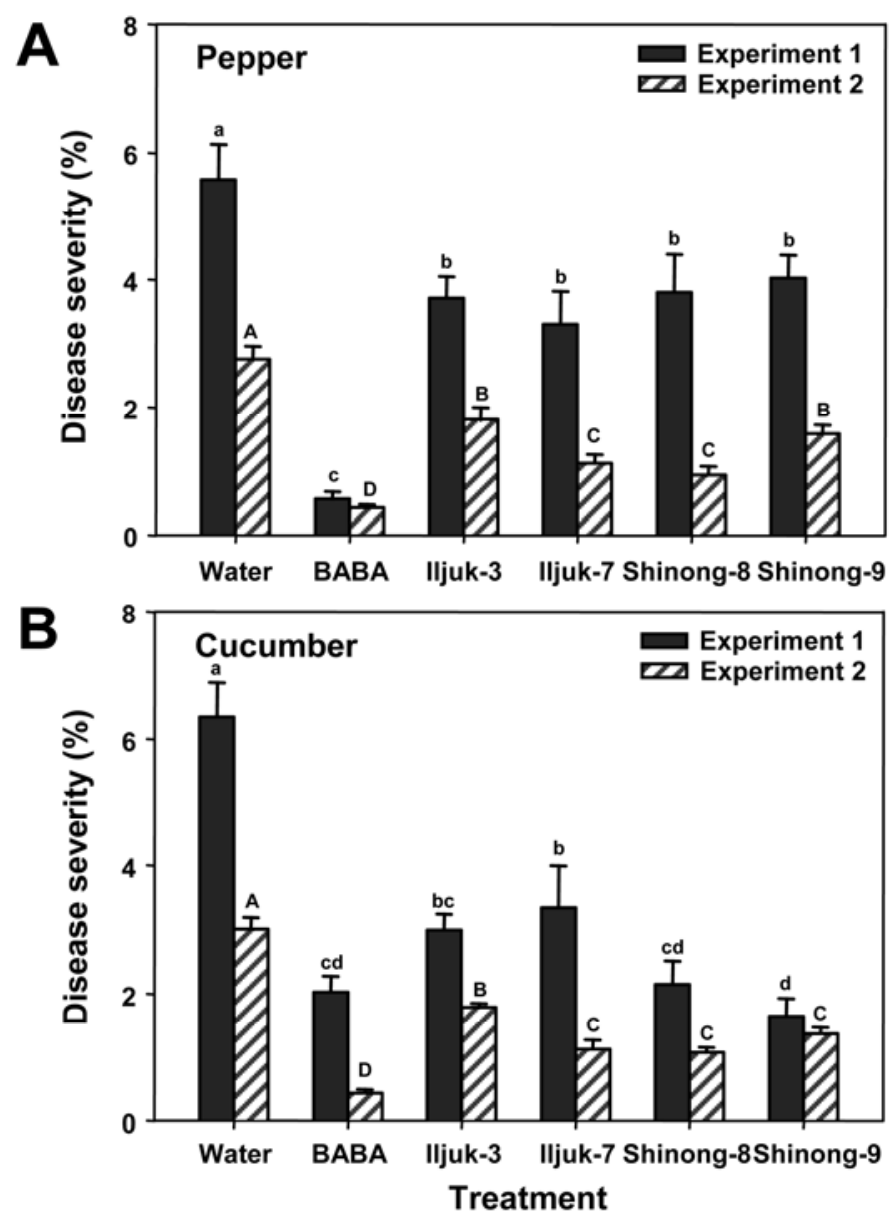

Fig. 6. Disease severity (\%) of A, Colletotrichum coccodes on the third leaves of 5-week-old pepper plants and $\mathbf{B}, \mathbf{C}$. orbiculare on the first leaves of 2-week-old cucumber seedlings after treatment with water extracts of composts, Iljuk-3 (10\%, wt/vol), Iljuk-7 (10\%, wt/vol), Shinong-8 (5\%, wt/vol), Shinong-9 (5\%, wt/vol), DL- $\beta$-amino butyric acid (BABA, positive control), or sterile distilled water (negative control) 5 days after inoculation. Leaves of the pepper plants and cucumber seedlings root-drenched with the treatments were inoculated with the pathogens 3 and 5 days after treatment, respectively. Each bar represents the standard error of the mean of 10 replications. Different small or capital letters on the bars indicate significant differences between treatments at $P<0.05$. No disease symptoms were observed in the uninoculated leaves of pepper plants and cucumber seedlings. 


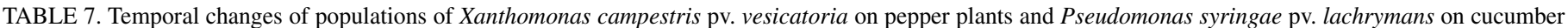

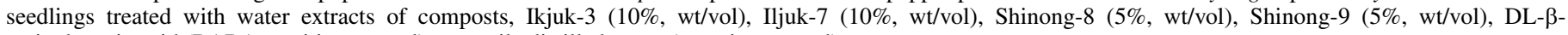
aminobutyric acid (BABA, positive control), or sterile distilled water (negative control)

\begin{tabular}{|c|c|c|c|c|}
\hline \multirow[b]{2}{*}{ Bacterium, treatment } & \multicolumn{4}{|c|}{ Bacterial population $(\log \mathrm{CFU} / \mathrm{g} \text { dry weight of leaf })^{\mathrm{x}}$} \\
\hline & 0 DAI & $1 \mathrm{DAI}$ & 3 DAI & 5 DAI \\
\hline \multicolumn{5}{|c|}{ X. campestris pv. vesicatoria ${ }^{\mathrm{y}}$} \\
\hline Water & $4.75 \pm 0.07 \mathrm{aD}$ & $6.81 \pm 0.02 \mathrm{a}-\mathrm{cC}$ & $9.06 \pm 0.05 \mathrm{aB}$ & $9.96 \pm 0.06 \mathrm{aA}$ \\
\hline BABA & $4.69 \pm 0.06 \mathrm{abD}$ & $6.69 \pm 0.07 \mathrm{cC}$ & $8.89 \pm 0.07 \mathrm{bB}$ & $9.73 \pm 0.09 \mathrm{bA}$ \\
\hline Iljuk-3 & $4.51 \pm 0.09 \mathrm{bD}$ & $6.80 \pm 0.06 \mathrm{a}-\mathrm{cC}$ & $9.03 \pm 0.05 \mathrm{abB}$ & $9.91 \pm 0.05 \mathrm{abA}$ \\
\hline Iljuk-7 & $4.54 \pm 0.06 \mathrm{abD}$ & $6.72 \pm 0.05 \mathrm{bcC}$ & $8.91 \pm 0.06 \mathrm{abB}$ & $9.82 \pm 0.06 \mathrm{abA}$ \\
\hline Shinong-8 & $4.65 \pm 0.07 \mathrm{abD}$ & $6.89 \pm 0.05 \mathrm{aC}$ & $9.08 \pm 0.07 \mathrm{aB}$ & $9.99 \pm 0.07 \mathrm{aA}$ \\
\hline Shinong-9 & $4.59 \pm 0.10 \mathrm{abD}$ & $6.87 \pm 0.05 \mathrm{abC}$ & $9.00 \pm 0.07 \mathrm{abB}$ & $9.94 \pm 0.06 \mathrm{aA}$ \\
\hline \multicolumn{5}{|c|}{ P. syringae pv. lachrymans $\mathrm{z}^{\mathrm{z}}$} \\
\hline Water & $6.20 \pm 0.03 \mathrm{bD}$ & $7.24 \pm 0.02 \mathrm{aC}$ & $8.28 \pm 0.10 \mathrm{abB}$ & $8.58 \pm 0.02 \mathrm{aA}$ \\
\hline BABA & $6.16 \pm 0.04 \mathrm{bD}$ & $7.19 \pm 0.07 \mathrm{aC}$ & $8.06 \pm 0.10 \mathrm{bB}$ & $8.37 \pm 0.05 \mathrm{bA}$ \\
\hline Iljuk-3 & $6.14 \pm 0.02 \mathrm{bD}$ & $7.21 \pm 0.03 \mathrm{aC}$ & $8.18 \pm 0.03 \mathrm{bB}$ & $8.51 \pm 0.05 \mathrm{aA}$ \\
\hline Iljuk-7 & $6.23 \pm 0.03 \mathrm{bC}$ & $7.16 \pm 0.02 \mathrm{aB}$ & $8.48 \pm 0.09 \mathrm{aA}$ & $8.59 \pm 0.05 \mathrm{aA}$ \\
\hline Shinong-8 & $6.35 \pm 0.06 \mathrm{aD}$ & $7.25 \pm 0.03 \mathrm{aC}$ & $8.24 \pm 0.08 \mathrm{bB}$ & $8.59 \pm 0.05 \mathrm{aA}$ \\
\hline Shinong-9 & $6.24 \pm 0.02 \mathrm{abD}$ & $7.21 \pm 0.02 \mathrm{aC}$ & $8.16 \pm 0.05 \mathrm{bB}$ & $8.61 \pm 0.05 \mathrm{aA}$ \\
\hline
\end{tabular}

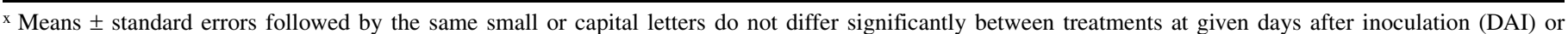
between DAIs at a given treatment according to least significant difference test at $P<0.05$. Values are means of eight replications for $X$. campestris pv. vesicatoria and six replications for $P$. syringae pv. lachrymans.

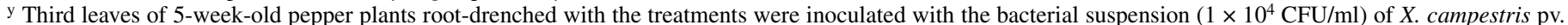
vesicatoria 3 days after treatment. Pathogen population in the leaves was determined on Tween B medium $0,1,3$, and 5 DAI.

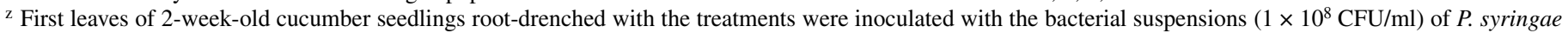
pv. lachrymans 5 days after treatment. Pathogen population in the leaves was determined on Pseudomonas agar F medium 0 , 1, 3, and 5 DAI.

peroxide generation in the leaves and lignin accumulation in the stems. Based on these results, the tested CWE increased peroxidase activity in pepper, which may have led to enhanced structural defenses through higher lignin accumulation in stems. Previously, Bolwell and Wojtaszek (5) and Quiroga et al. (44) observed that increased peroxidase activity was involved in lignin composition or synthesis as defense mechanisms. More recently, Choi et al. (11) reported that peroxidase expression was responsible for reactive oxygen species generation and $P R$ gene expression in pepper plants.

Taken together, these results indicate that a heat-stable chemical(s) present in the CWE tested in this study can suppress root and foliar infection by $P$. capsici in pepper plants. These suppressions might result from direct inhibition of development and population of $P$. capsici for root infection, as well as indirect inhibition of foliar infection through ISR. In addition, ISR induced by the CWE generated broad-spectrum protection not only against infection by $P$. capsici and $C$. coccodes on pepper but also against infection by $C$. orbiculare on cucumber; however, the ISR failed to protect the plants against infection by $X$. campestris pv. vesicatoria on pepper and P. syringae pv. lachrymans on cucumber.

\section{ACKNOWLEDGMENTS}

This study was conducted with the support of the Cooperative Research Program for Agricultural Science \& Technology Development (Project No. 200901OFT102967499), Rural Development Administration, Republic of Korea. We thank the commercial compost facilities, especially Iljuk and Shinong, which allowed us to collect compost samples; C.-M. Ryu for providing the strain of Pseudomonas syringae pv. lachrymans; and B. S. Kim, C.-M. Ryu, and H. W. Choi for reading this manuscript.

\section{LITERATURE CITED}

1. Abeles, F. B., Bosshart, R. P., Forrence, L. E., and Habig, W. H. 1970. Preparation and purification of glucanase and chitinase from bean leaves. Plant Physiol. 47:129-134.

2. Al-Dahmani, J. H., Abbasi, P. A., Miller, S. A., and Hoitink, H. A. J. 2003. Suppression of bacterial spot of tomato with foliar sprays of compost extracts under greenhouse and field conditions. Plant Dis. 87:913-919.

3. Atiyeh, R. M., Edwards, C. A., Subler, S., and Metzger, J. D. 2001. Pig manure vermicompost as a component of a horticultural bedding plant medium: Effects on physicochemical properties and plant growth. Bioresource Technol. 78:11-20.

4. Biemelt, S., Tschiersch, H., and Sonnewald, U. 2004. Impact of altered gibberellin metabolism on biomass accumulation, lignin biosynthesis, and photosynthesis in transgenic tobacco plants. Plant Physiol. 135:254-265.

5. Bolwell, G. P., and Wojtaszek, P. 1997. Mechanisms for the generation of reactive oxygen species in plant defence- $\mathrm{a}$ broad perspective. Physiol. Mol. Plant Pathol. 51:347-366.

6. Boulter, J. I., Boland, G. J., and Trevors, J. T. 2000. Compost: A study of the development process and end-product potential for suppression of turfgrass disease. World J. Microbiol. Biotechnol. 16:115-134.

7. Bradford, M. M. 1976. A rapid and sensitive method for the quantitation of microgram quantities of protein utilizing the principle of protein-dye binding. Anal. Biochem. 72:248-254.

8. Cameron, R. K., Paiva, N. L., Lamb, C. J., and Dixon, R. A. 1999. Accumulation of salicylic acid and PR-1 gene transcripts in relation to the systemic acquired resistance (SAR) response induced by Pseudomonas syringae pv. tomato in Arabidopsis. Physiol. Mol. Plant Pathol. 55:121-130.

9. Chen, W., Hoitink, H. A. J., and Schmitthenner, A. F. 1987. Factors affecting suppression of Pythium damping-off in container media amended with composts. Phytopathology 77:755-760.

10. Choi, H.-W., Chung, I.-M., Sin, M. H., Kim, Y. S., Sim, J.-B., Kim, J.-W., Kim, K. D., and Chun, S.-C. 2007. The effect of spent mushroom sawdust compost mixes, calcium cyanamide and solarization on basal stem rot of the cactus Hylocereus trigonus caused by Fusarium oxysporum. Crop Prot. 26:162-168.

11. Choi, H. W., Kim, Y. J., Lee, S. C., Hong, J. K., and Hwang, B. K. 2007. Hydrogen peroxide generation by the pepper extracellular peroxidase CaPO2 activates local and systemic cell death and defense response to bacterial pathogens. Plant Physiol. 145:890-904.

12. Conn, K. L., Tenuta, M., and Lazarovits, G. 2005. Liquid swine manure can kill Verticillium dahliae microsclerotia in soil by volatile fatty acid, nitrous acid, and ammonia toxicity. Phytopathology 95:28-35.

13. Cronin, M. J., Yohalem, D. S., Harris, R. F., and Andrews, J. H. 1996 Putative mechanism and dynamics of inhibition of the apple scab pathogen Venturia inaequalis by compost extracts. Soil Biol. Biochem. 28:1241-1249.

14. Diab, H. G., Hu, S., and Benson, D. M. 2003. Suppression of Rhizoctonia solani on impatiens by enhanced microbial activity in composted swine waste-amended potting mixes. Phytopathology 93:1115-1123.

15. Edmeades, D. C. 2003. The long-term effects of manures and fertilisers on soil productivity and quality: A review. Nutr. Cycl. Agroecosyst. 66:165-180.

16. El-Masry, M. H., Khalil, A. I., Hassouna, M. S., and Ibrahim, H. A. H. 2002. In situ and in vitro suppressive effect of agricultural composts and their water extracts on some phytopathogenic fungi. World J. Microbiol. Biotechnol. 18:551-558.

17. Erhart, E., Burian, K., Hartl, W., and Stich, K. 1999. Suppression of Pythium ultimum by biowaste composts in relation to compost microbial 
biomass, activity and content of phenolic compounds. J. Phytopathol. 147:299-305

18. Fichtner, E. J., Benson, D. M., Diab, H. G., and Shew, H. D. 2004. Abiotic and biological suppression of Phytophthora parasitica in a horticultural medium containing composted swine waste. Phytopathology 94:780-788.

19. Gay, C., Collins, J., and Gebicki, J. M. 1999. Determination of iron in solutions with the ferric-xylenol orange complex. Anal. Biochem. 273:143-148.

20. Hammerschmidt, R., Nuckles, E. M., and Kuć, J. 1982. Association of enhanced peroxidase activity with induced systemic resistance of cucumber to Colletotrichum lagenarium. Physiol. Plant Pathol. 20:73-82.

21. Hausbeck, M. K., and Lamour, K. H. 2004. Phytophthora capsici on vegetable crops: Research progress and management challenges. Plant Dis. 88:1292-1303.

22. Hoitink, H. A. J., and Boehm, M. J. 1999. Biocontrol within the context of soil microbial communities: A substrate-dependent phenomenon. Annu. Rev. Phytopathol. 37:427-446.

23. Hwang, B. K., and Kim, C. H. 1995. Phytophthora blight of pepper and its control in Korea. Plant Dis. 79:221-227.

24. Joshi, D., Hooda, K. S., Bhatt, J. C., Mina, B. L., and Gupta, H. S. 2009. Suppressive effects of composts on soil-borne and foliar diseases of French bean in the field in the western Indian Himalayas. Crop Prot. 28:608-615.

25. Kavroulakis, N., Ehaliotis, C., Ntougias, S., Zervakis, G. I., and Papadopoulou, K. K., 2005. Local and systemic resistance against fungal pathogens of tomato plants elicited by a compost derived from agricultural residues. Physiol. Mol. Plant Pathol. 66:163-174.

26. Kim, H. S., Sang, M. K., Jeun, Y.-C. Hwang, B. K., and Kim, K. D. 2008. Sequential selection and efficacy of antagonistic rhizobacteria for controlling Phytophthora blight of pepper. Crop Prot. 27:436-443.

27. Kim, K. D., Nemec, S., and Musson, G. 1997. Control of Phytophthora root and crown rot of bell pepper with composts and soil amendments in the greenhouse. Appl. Soil Ecol. 5:169-179.

28. Kim, K. D., Nemec, S., and Musson, G. 2000. Effects of composts and soil amendments on physicochemical properties of soils in relation to Phytophthora root and crown rot of bell pepper. Plant Pathol. J. 16:283285.

29. Kim, K. D., Nemec, S., and Musson, G. 1997. Effects of composts and soil amendments on soil microflora and Phytophthora root and crown rot of bell pepper. Crop Prot. 16:165-172

30. Kim, Y. J., and Hwang, B. K. 2000. Pepper gene encoding a basic pathogenesis-related 1 protein is pathogen and ethylene inducible. Physiol. Plant. 108:51-60.

31. Kim, Y. J., Hwang, B. K., and Park, K. W. 1989. Expression of age-related resistance in pepper plants infected with Phytophthora capsici. Plant Dis. 73:745-747.

32. Kim, Y. S., Jang, B., Chung, I.-M., Sang, M. K., Ku, H.-M., Kim, K. D., and Chun, S.-C. 2008. Enhancement of biocontrol activity of antagonistic Chryseobacterium strain KJ1R5 by adding carbon sources against Phytophthora capsici. Plant Pathol. J. 24:164-170.

33. Kloepper, J. W., Tuzun, S., Zehnder, G. W., and Wei, G. 1997. Multiple disease protection by rhizobacteria that induce systemic resistancehistorical precedence. Phytopathology 87:136-137.

34. Kwack, M. S., Kim, E. N., Lee, H., Kim, J.-W., Chun, S.-C., and Kim, K. D. 2005. Digital image analysis to measure lesion area of cucumber anthracnose by Colletotrichum orbiculare. J. Gen. Plant Pathol. 71:418421.

35. Lee, C.-H. 2000. Changes of the chemical properties of organic byproduct fertilizers during the composting and effect of those particle size and bulk density on soil hydraulic conductivity. Ph.D. dissertation, Korea University, Seoul, Republic of Korea. (In Korean)

36. Lee, C.-H., Ok, Y.-S., Yoon, Y.-M., Kim, D.-Y., Lim, S.-K., Eom, K.-C., and Kim, J.-G. 2006. Physical and chemical quality of organic byproduct fertilizers by composting of livestock manure in Korea. Korean J. Soil Sci. Fertil. 39:224-229.
37. Lee, S. C., and Hwang, B. K. 2005. Induction of some defense-related genes and oxidative burst is required for the establishment of systemic acquired resistance in Capsicum annиum. Planta 221:790-800.

38. Levene, H. 1960. Contributions to Probability and Statistics: Essays in Honor of Harold Hotelling. Stanford University Press, Stanford, CA, U.S.A.

39. McGuire, R. G., Jones, J. B., and Sasser, M. 1986. Tween media for semiselective isolation of Xanthomonas campestris pv. vesicatoria from soil and plant material. Plant Dis. 67:779-781.

40. Ministry of Environment. 2008. The forth basic plan for recycling resources. Publication no. 11-1480000-000894-01, Kwacheon, Republic of Korea. (In Korean)

41. Nelson, T. E., Scaletti, J. V., Smith, F., and Kirkwood, S. 1963. The use of enzymes in structural studies on polysaccharides. I. The mode of attack of a $\beta$-D-(1 $\rightarrow 3)$-glucanase on laminarin. Can. J. Chem. 41:1671-1678.

42. Palloix, A., Daubeze, A. M., and Pochard, E. 2008. Phytophthora root rot of pepper influence of host genotype and pathogen strain on the inoculum density-disease severity relationships. J. Phytopathol. 123:25-33.

43. Parra, G., and Ristaino, J. B. 2001. Resistance to mefenoxam and metalaxyl among field isolates of Phytophthora capsici causing Phytophthora blight of bell pepper. Plant Dis. 85:1069-1075.

44. Quiroga, M., Guerrero, C., Botella, M. A., Barceló, A., Amaya, I., Medina, M. I., Alonso, F. J., Forchetti, S. M., Tigier, H., and Valpuesta, V. 2000. A tomato peroxidase involved in the synthesis of lignin and suberin. Plant Physiol. 122:1119-1127.

45. Ramamoorthy, V., Viswanathan, R., Raguchander, T., Prakasam, V., and Samiyappan, R. 2001. Induction of systemic resistance by plant growth promoting rhizobacteria in crop plants against pests and diseases. Crop Prot. 20:1-11.

46. Ristaino, J. B., and Johnston, S. A. 1999. Ecologically based approaches to management of Phytophthora blight on bell pepper. Plant Dis. 83:10801089.

47. Sang, M. K., Chun, S.-C, and Kim, K. D. 2008. Biological control of Phytophthora blight of pepper by antagonistic rhizobacteria selected from a sequential screening procedure. Biol. Control 46:424-433.

48. Sang, M. K., Oh, J. Y., and Kim, K. D. 2007. Root-dipping application of antagonistic rhizobacteria for the control of Phytophthora blight of pepper under field conditions. Plant Pathol. J. 23:109-112.

49. Scheuerell, S. J., and Mahaffee, W. F. 2004. Compost tea as a container medium drench for suppressing seedling damping-off caused by Pythium ultimum. Phytopathology 94:1156-1163.

50. Scheuerell, S. J., Sullivan, D. M., and Mahaffee, W. F. 2005. Suppression of seedling damping-off caused by Pythium ultimum, P. irregulare, and Rhizoctonia solani in container media amended with a diverse range of Pacific Northwest compost sources. Phytopathology 95:306-315.

51. Solel, Z., and Pinkas, Y. 1984. A modified selective medium for detecting Phytophthora cinnamomi on avocado roots. Phytopathology 84:506-508.

52. Vallad, G. E., Cooperband, L., and Goodman, R. M. 2003. Plant foliar disease suppression mediated by composted forms of paper mill residuals exhibits molecular features of induced resistance. Physiol. Mol. Plant Pathol. 63:65-77.

53. Vallad, G. E., and Goodman, R. M. 2004. Systemic acquired resistance and induced systemic resistance in conventional agriculture. Crop Sci. 44:1920-1934.

54. Verhagen, B. W. M., Glazebrook, J., Zhu, T., Chang, H.-S., van Loon, L. C., and Pieterse, C. M. J. 2004. The transcriptome of rhizobacteriainduced systemic resistance in Arabidopsis. Mol. Plant-Microbe Interact. 17:895-908.

55. Walters, D. R. 2009. Are plants in the field already induced? Implications for practical disease control. Crop Prot. 28:459-465.

56. Zhang, W., Han, D. Y., Dick, W. A., Davis, K. R., and Hoitink, H. A. J. 1998. Compost and compost water extract-induced systemic acquired resistance in cucumber and Arabidopsis. Phytopathology 88:450-455.

57. Zmora-Nahum, S., Danon, M., Hadar, Y., and Chen, Y. 2008. Chemical properties of compost extracts inhibitory to germination of Sclerotium rolfsii. Soil Biol. Biochem. 40:2523-2529. 